University of New Hampshire

University of New Hampshire Scholars' Repository

$9-1-2007$

\title{
The big questions of personality psychology: Defining common pursuits of the discipline
}

John D. Mayer

University of New Hampshire, Durham, jack.mayer@unh.edu

Follow this and additional works at: https://scholars.unh.edu/psych_facpub

Comments

Mayer, J. D. (2007). The big questions of personality psychology: Defining common pursuits of the discipline.

Imagination, Cognition, and Personality, 27, 3-26. Copyright 2007 (Sage). Reprinted by permission of SAGE

Publications. https://dx.doi.org/10.2190/IC.27.1.b

\section{Recommended Citation}

Mayer, J. D. (2007). The big questions of personality psychology: Defining common pursuits of the discipline. Imagination, Cognition, and Personality, 27, 3-26.

This Article is brought to you for free and open access by the College of Liberal Arts (COLA) at University of New Hampshire Scholars' Repository. It has been accepted for inclusion in Psychology Scholarship by an authorized administrator of University of New Hampshire Scholars' Repository. For more information, please contact Scholarly.Communication@unh.edu. 


\title{
RUNNING HEAD: BIG QUESTIONS
}

\section{The Big Questions of Personality Psychology: Defining Common Pursuits of the Discipline}

\author{
John D. Mayer
}

\begin{abstract}
AUTHOR NOTES
My discussion of the big questions of personality psychology more generally was enriched by comments from several historians of psychology including William Harris, William Woodward, and Lawrence Smith; their comments were invaluable; the article was strengthened further by comments from Zorana Ivcevic.

Correspondence regarding this manuscript may be addressed to John D. Mayer, Department of Psychology, 10 Library Way, University of New Hampshire, Durham, NH 03824; e-mail: jack.mayer@unh.edu.
\end{abstract}

\begin{abstract}
Big questions of personality are those that are simple, important and often have been asked repeatedly over time, such as "Who am I?", "What is human nature?" and "How does personality work?". This article identifies 20 big questions relevant to personality psychology. The historical background of each question is briefly described, and the questions are arranged into a model of big questions about personality. The questions, it is argued, both reflect and help to clarify the intrinsic interest in studying personality psychology. They offer insight into the cohesive nature of the field of personality by helping to define its common pursuits.
\end{abstract}

\section{Prepublication version of:}

Mayer, J. D. (2007). The big questions of personality psychology: Defining common pursuits of the discipline. Imagination, Cognition, and Personality, 27, 3-26. 


\title{
The Big Questions of Personality Psychology: Defining Common Pursuits of the Discipline
}

\author{
In some ways our ancestors knew more than we do. This is partly \\ because...we have become specialists and have sacrificed the broader \\ view as we pursue our specialties. Partly, we tend to take our problems \\ from the laboratory, not from life as they did...(Henle, 1976, p. 18)
}

Big questions are defined here as those questions that are simple, important, and central to many people's lives. Such questions often have persisted from ancient times to the present - one index of their significance (Watson, 1967). Examples include, "How did life begin?" and "What is human nature?" This article explores some of the big questions of personality psychology to see whether such questions might provide a unifying perspective on the field. The field of personality psychology often is viewed as fragmented and specialized. One of the field's founders, Gordon Allport, hoped that broader views of the person were possible (Allport, 1964). Big questions offer one pathway to a broader view of the field and its pursuits.

Big questions of personality also can be of importance because understanding their history provides us with a more reliable idea of why we study what we do today (Henle, 1976; Jaynes, 1973, p. xi). Sciences often progress historically rather than logically, leaving and then returning to central topics (Jaynes, 1973). History broadens one's appreciation for the present and how it has come to be. Intellectual history, more specifically, can liberate us from intellectual fashion and free us to think freshly about problems (Henle, 1976; Jaynes, 1973, p. xi).

Personality psychologists often take the broadest possible perspective in examining an individual's mental life; that is, personality psychology concerns the development of an integrated picture of how motives, emotions, thought, the self, and other major psychological systems work together (Mayer, 2005a; Pervin, 2002; Sears, 1950; Wundt, 1897). The personality psychologist's breadth allows for a natural connection between the science of psychology, on the one hand, and philosophical questions about human nature and how to live one's life, on the other.

The influential mid-20 $0^{\text {th }}$-century textbook Theories of Personality advanced the idea that personality psychologists necessarily "dealt with issues which seem central and important to the typical observer of human behavior...", and traced the field's origins to "...the great classical scholars such as Hippocrates, Plato, \& Aristotle..." (Hall \& Lindzey, 1957, pp. 2, 5). Personologists freely drew on big questions from antiquity and posed their own as well (Allport, 1937, p. 48; Roback, 1927, p. ix). One early textbook, Explorations in Personality (Murray, 1938, p. 3), asked of the individual, "What can we know about him?" Today, the field's textbooks continue to ask such questions as: “...Who am I?" (Mischel, Shoda, \& Smith, 2004, p. 4), and "Why are people the way they are? Why am I the way I am?” (Pervin, Cervone, \& John, 2005, p. 5).

This article asks what the big questions of personality psychology are, how they can be organized, and what they tell us about the field's common pursuits. The "Background" section of this article considers the significance of big questions, and notes that there is no presently-accepted list of such questions. "A Representative List of Big 
Questions of Personality", collects 20 big questions relevant to personality psychology (and psychology more generally), and describes the context from which they emerged. A "Model of Big Questions of Personality," presents one view of why the questions may be important to the individual asking them. Finally, the "Discussion" examines the advantages to the field and to those within it, of understanding such big questions.

\section{BACKGROUND}

A big question, as developed here: (a) can be put in simple form (e.g., "Is there free will?"), (b) is of general interest, (c) has been asked persistently across time and people(s), and (d) matters to how we live our life (e.g., "Who am I?"). These ideas can be organized and summarized in a definition: A big question is a type of question that is simple, important, of interest to people in general, and that has been asked persistently over the ages by philosophers, at least in part because the answer matters in regard to how we live our lives.

At a disciplinary level, interest in big questions helps provide a rationale and direction for the field. Their big nature suggests they draw on intrinsic motives that may in part drive both the scientists in the field and those who are interested in what those scientists have discovered (Ryan \& Deci, 2000). Asking and wondering about such questions can organize and direct our learning and foster a sense of mission (Bonwell \& Eisen, 1991; Hamilton, 1985). A clarified sense of mission, in turn, can promote unity and progress in an organization - in this case, a scientific field (Bart \& Baetz, 1998; Bart \& Tabone, 2000; Bartkus, Glassman, \& McAfee, 2000).

At a personal level, big questions emerge from our curiosity, wonderment and awe in response to the world. Such curiosity likely is functional and serves to direct people to consider what matters in their lives. For example, the questions often arise out of the specific issues a person is grappling with (Alexander, 1942; Woodhouse, 1984, p. 4). The way the questions ultimately are answered - in terms of constructing models of others and the world - will guide our interaction with others (Kelly, 1955; Mischel \& Shoda, 1995).

What is the difference between big questions of personality psychology and big questions of psychology more generally? Many big questions of personality psychology equally are questions of psychology. Examples include: "What is human nature?" and "Why do people differ from each other?" Big questions of personality, however, would not include those questions that pertain to more basic and discrete psychological systems that operate to support personality. Examples of big questions of psychology that are less applicable to personality include, "How do we see?" "How do we hear?", and "Do we think in images or words?". The latter questions, although big, deal with more specific systems underlying personality, and are less central to the function of personality as a whole.

Personality psychology sometimes is viewed as a house divided. It is divided by apparently divergent theories such as the psychodynamic, trait, and social cognitive which emphasize different topics and terminology, and divided also into specialized research programs (Allport, 1964; Carlson, 1971). Big questions potentially are relevant 
to many specific theories and research programs together. As such, they may offer a shared perspective as to what is important to study and why.

\section{A REPRESENTATIVE LIST OF BIG QUESTIONS OF PERSONALITY}

Big questions (and big issues) often are dealt with in psychology in general, and in personality psychology in particular. Such questions have appeared in the field's textbooks and in intellectual histories of the discipline. At the same time, no readilyaccessible, comprehensive list of such questions appears to have been compiled as-of-yet. At best such big questions, or something like them (e.g., big issues) are dealt with several at a time (e.g., Pervin, 2002). A more comprehensive list of such questions are identified in this section, preliminary to considering how they relate to the field of personality.

Method

To compile a list of the big questions of personality psychology, several research procedures were employed. First, the introductory chapters of several authoritative textbooks in personality psychology were consulted and major questions listed therein were considered for inclusion (e.g., Funder, 2001; e.g., Hall \& Lindzey, 1978; McAdams, 2000; Monte \& Sollod, 2003). Contemporary articles discussing major questions also were examined (Funder, 2001; McAdams, 1996; Watson, 1967). Second, early books in the field of personality psychology - particularly those with a specific emphasis on examining the development of philosophical questions - were examined (Allport, 1937; Jung, 1923; Roback, 1928). In all the forgoing cases, relevant primary sources were checked to verify the presence of big questions, and to search for associated questions. To avoid any missed questions and to fill in the background of those questions finally employed, intellectual histories of psychology also were consulted (Green \& Groff, 2003; Murphy \& Kovach, 1972; Robinson, 1976; Viney \& King, 2003).

In considering big questions, the inclusion criterion of "asked over the ages" was progressively relaxed as the introduction of a question became more recent. This exception was important because it permitted the inclusion of big scientific questions of relatively recent origin. Without these, the set of questions might seem inadvertently discontinuous with present concerns.

Such procedures were likely to result in the compilation of important big questions relevant to the field. At the same time, the set of questions identified ultimately depended on the specific references employed as starting points, and on subsequent research decisions as to which sources to check, and which questions to retain. So, the results reported below provide only one specific example of a group of questions central to the field; others are possible.

The Choice of 20 Questions

Many questions had several variations, and related sets of questions also seemed to exist. Closely-related questions were grouped into several preliminary categories that 
reappeared across intellectual histories of the field: (a) questions of human nature and its variations, (b) of consciousness, will, and spirituality, (c) of identity and living, (d) of the science of psychology, and (e) of the study of personality in specific. Later in the article, these questions will be slightly regrouped. For now, however, these categories are representative of the kinds of questions frequently examined.

As questions were collected, it appeared that approximately 20 key questions (and slight variations on them) would cover most of those relevant to personality psychology. The number 20 is often associated with lists of questions, likely because of its connection to the well-known game of 20 questions. (In that game, a person tries to guess what someone else is thinking by asking 20 dichotomous questions about it). A decision was made to limit the list to 20 questions, therefore, as a convenient target.

The 20 questions are listed in Table 1. They range from the ancient and general, "What is human nature?" to the more specific and concrete, "How does personality work?" In between are many other questions of note.

A Synoptic Overview

of the 20 Questions Themselves

The reasoning behind including each group of questions, and the specific questions, is described briefly next. Proceeding according to the categories described above (e.g., questions of human nature, of consciousness and will, etc.), (a) a sketch of some historical background relevant to the question or questions is provided, (b) primary and secondary source material related to the question are cited, along with any noteworthy facts related to the question (as space permits), and (c) the question(s)' persisting relevance to the present-day field is considered.

Such overviews are prone to many criticisms, including that their simplifications promote inaccuracies, and even mythmaking. Nonetheless, such big-picture scholarship can provide a synthesis of knowledge that is readily accessible relative to lengthier indepth examinations, and that is general in its perspective relative to narrowly-focused coverage (Smith, 1998). So, although this synopsis at times may sacrifice nuance, subtlety, and completeness there are, arguably, specific benefits to describing the 20 questions as a group and appreciating what such a list of questions might say, collectively, about personality psychology.

\section{Human Nature Considered}

Any of several psychological questions would be reasonable candidates to lead off the list including: Why are people the same or different? or What is it like to be human? The ancient world gave rise to many questions specifically related to being human, its scope, and its varieties. One central concern of those in Antiquity - and of consequence to choosing a first question - was the degree to which human beings were unique among other living things. The ancients wondered how the human psyche might compare to a similar entity possessed by animals, and, how it might be similar or different to something possessed by the gods. Aristotle concludes that animal souls are similar to human souls in sharing psychic faculties of nutrition, reproduction, and motion, as well as feelings and intelligence. The chief difference of human beings from the 
animals, he believed, is the human's ability to engage in reasoning and abstract thought that is, the capacity to grasp universals (Aristotle, 1976; Robinson, 1976, p. 49). Table 1

Overview of the Big Questions of Personality Psychology

\begin{tabular}{lll}
\hline Questions About... & Number & \\
\hline Human Nature and & 1 & What is human nature? \\
its Variation & 2 & To what degree is personality innate or learned? \\
& 3 & Why are people different from one another? \\
& 4 & How do groups differ from one another in their \\
Consciousness, Will, & 5 & psychology? \\
and Spirituality & 6 & Can human beings know God? \\
& 7 & Are mind and body the same? \\
Identity & 8 & What is it like to be a person? \\
& 9 & Who am I? \\
& 10 & How shall I live my life? \\
The Science of & 11 & What is my future? \\
Personality & 12 & Why is it so hard to know ourselves? \\
& 13 & Is it possible to have a science of psychology? \\
The Study of & 14 & Where is personality? \\
Personality & 16 & What do we know when we know a person? \\
& 17 & How does personality work? \\
& 18 & How should personality be divided? \\
& 19 & Does personality exist? \\
& 20 & How is personality expressed in the situation? \\
& & Why do people stay the same or change? \\
\hline
\end{tabular}

This wonderment concerning what it was to be human continued through the Middle Ages and beyond. Augustine used a theological argument to distinguish between man and animal - that the Bible gave man, who was rational, dominion over animals, who were irrational and lacked a divine soul. Augustine's purpose was to support a view of natural equality among human beings, and their superiority over animals (Robinson, 1976, p. 79). The ancient origins and persistence of the inquiry through the present, regarding who we are as a species, led to the choice of Question 1: What is human nature?

\section{Questions About the Human Nature and Its Variations}

\section{The Origins of Mind}

Although the ancients did not yet speak of personality, they did wonder where a person's knowledge (e.g., mental models) came from, and, because a person's mental 
models of the world are central to personality, questions about the origins of knowledge are similarly questions about the origins of personality.

Regarding those, Plato believed that knowledge was available innately in the human mind; that is, even before the person engaged in formal learning. Socrates, as described in Plato's dialogue Meno, showed how Meno's uneducated young servant could discover the Pythagorean theorem on his own, using only his logic - and guidance from a philosopher. For Plato, truths are known but camouflaged (Green \& Groff, 2003, p. 53; Robinson, 1976, pp. 25, 39). This idea is echoed in part in contemporary research on basic or innate aspects of perception and problem-understanding (Chomsky, 1965; Kunzendorf, 1982).

Others viewed the mind's development as more dependent on the environment. Regarding intellect and memory, David Hume (1711-1776) argued that knowledge was created entirely from the senses. From sensed-ideas, more complex ideas were constructed, until, finally, sophisticated reasoning took place.

Those big questions are investigated today, for example, when inquiring into which aspects of personality are determined by genes, which by the environment, and which by their interaction. Such issues can be represented as in Question 2: To what degree is personality innate or learned?

The Variety of Human Natures

Another question of Antiquity concerned questions of types and differences of characters. In the $3^{\text {rd }}$ century BCE, Theophrastus asked, "Why it is that while all Greece lies under the same sky and all the Greeks are educated alike, it has befallen us to have characters variously constituted?" (transl. in Roback, 1928, p. 9). His "Characters" described a number of types. For example, the extrovert will:

... sit down close beside somebody he does not know, and begin talk with a eulogy of his own life, and then relate a dream he had the night before, and after that tell dish by dish what he had for supper... he will remark that we are by no means the men we were, and... there's a ship of strangers in town...And if you let him go on he will never stop. (Theophrastus, 372-287 B.C./1929).

Theophrastus' work began the characterological school of literature by which different types of people were compared, differentiated, and described. This literature became a basis of typological research during the beginnings of modern psychology (Jung, 1923; Roback, 1928). The ancient origins of character study argue for the inclusion of Question 3: Why are people different from one another?

The Exploration of Groups

The French sociologist Charles Fourier (1772-1837) divided human beings first into men and women, and from there, into 810 different souls or characters, distributed into sixteen tribes and thirty-two choirs. Some examples are the ambitious, the avaricious, those with luxism (who chase luxury), and tactism (who look for physical pleasure). Fourier was a utopian thinker who tried to envision how character and society might find peace with one another. For Fourier: "the unit of harmony is not the individual or even the family. It is the characterial community" (Roback, 1928, p. 168). The characterial community is a community of people with different interests and passions who complement one another precisely through those differences. Fourier 
shifted attention from the individual to how different types live together. By the mid- $20^{\text {th }}$ century, books on differential psychology (i.e., individual and group differences), examined the mental status of men and women, geniuses and the "feeble-minded," and individuals of different cultures, races, and socio-economic status (Anastasi \& Foley, 1949). Thus, Question 4: How do groups differ from one another in their psychology? Questions of Consciousness, Will and Spirituality

\section{Questions of Spirituality}

According to one authority, during the 15 centuries from $200 \mathrm{CE}$ to $1800 \mathrm{CE}$, there is no record of a serious psychological work devoid of religious discussion (Robinson, 1976, p. 234). Any intellectual history of the field must grapple with these works, some of which seem primarily religious today: e.g., "Can man know God?," "What are peoples' duties to God?," and "What is sin?" (Robinson, 1976, p. 100-101). To represent the spiritual perspective of the time the list includes Question 5: Can human beings know God?

Spiritual considerations of human nature raised new secular issues about the human psyche. In Ancient Greece, Democritus had judged soul, mind (nous), and body to be the same and all reducible to atoms (Green \& Groff, 2003, p. 36). For thinkers such as Aristotle, the soul was subject to philosophical elucidation independent of theological considerations (Murphy \& Kovach, 1972, p. 12).

Yet, if God is eternal, non-material, and bestows life - in the form of a soul could that soul be eternal as well? St. Thomas Aquinas viewed the integration of soul and body as a natural phenomenon (Viney \& King, 2003). Descartes suggested that the soul interacted with the body at the pineal gland, leaving the brain as a natural organ and, not coincidentally, allowing for its empirical study since it was non-spiritual (Descartes, 1641/1968). Spinoza suggested that soul and body are the same, but looked at from different perspectives (Murphy \& Kovach, 1972, p. 23; Robinson, 1976, pp. 203, 213). This debate remains with us today in regard to Question 6: Are mind and body the same?

The idea that there existed an all-powerful God also raised the question of whether peoples' fates are entirely determined. A particularly important question that arose and remains of concern today, is "What is the nature and status of human will?" (Robinson, 1976, p. 78) - or more simply put in Question 7: Is there free will? This problem grew out of theological debates, but it is relevant to an often deterministic science as well (Bain, 1868/1973, pp. 396-428). The question is posed more technically nowadays, as in: "To what extent are people responsible for their own actions and to what extent are those acts determined?" (Flanagan, 2002).

The Beginnings of Phenomenology

One great divide between consciousness, or the psyche, and the rest of the mind is that it feels like something to be conscious. The German philosopher George Friedrich Hegel (1770-1831) developed phenomenology as a means of analyzing the experiences of consciousness (Robinson, 1976, p. 284). He noted that there existed different levels of consciousness. Of these levels of consciousness, the most basic - forming a backdrop to all other forms of awareness - is a stance of being-ness - an undifferentiated aliveness he believed was shared with other parts of living nature. 
In the human being, this awareness gradually differentiates into a sense of self and otherness, and, finally, into a sense of reflective self-awareness (Stace, 1924/1955, pp. 328 and 343). Wilhelm Wundt, who founded the first psychological laboratory, regularly described his psychology as centrally concerned with "the facts and internal organization of consciousness" - and a "manifold of consciousness," which he believed could be studied empirically (Robinson, 1976, 226). Perhaps more centrally, this position continues to find emphasis in existential and related theories (Husserl, 1913/1931). A recent existential question, is "What is it like to be a bat?" (Nagel, 1981). Its phrasing is borrowed for Question 8: What is it like to be a person?

Questions of Identity and Living:

The "Who Am I" Questions

\section{Seeking an Identity}

Questions of identity join our concepts of human nature in general with the nature of our conscious self-awareness. Identity questions reflect people's questioning of who they are.

During the years from 800 BCE to approximately 200 CE, Athenians or Spartans with a question of significance about the city-states of Ancient Greece would make their destination Delphi. At Delphi, a temple stood, erected to the God Apollo (La CosteMesselière, 1950). At its entrance, carved into a column by Chiron of Sparta, was the command "Know thyself" (Diodurus, 1935/1960, Book IX, 9. 10). Plato has Socrates discuss self-knowledge in many points in his dialogues, and Socrates professes to be interested in self-knowledge above all else (Griswold, 1986, p. 68).

Sir Francis Bacon (1561-1626) wrote two millennia later, in his "Proficiency and Advancement of Learning" "We come therefore now to that knowledge whereunto the ancient oracle directs us, which is knowledge of ourselves, which deserveth the more accurate handling, by how much it toucheth us more nearly..." (Bacon, 1605/1878, p. 236). All this and much more argues for Question 9: Who am I?

Conduct and the Search for a Life Path

In about 200 BCE, Qohelet (Ecclesiastes) asked the question, "What profit has a man of all his labour wherein he labours under the sun?" (Jerusalem Bible, 1992, p. 876). Although the concrete issue here is "Why work?" it is only an example of his broader concerns: whether living one way rather than another is best. Qohelet's fully selfconscious analysis of how to live has been referred to as one of the best examples of modern consciousness in ancient literature (Jaynes, 1976, p. 296). For Quohelet, the person must understand how to live in various times. "To everything there is a season, and a time to every purpose under heaven." (Jerusalem Bible, 1992, Qohelet, p. 878). The central question is Question 10: How shall I live my life?

\section{Seeing Into the Future}

To retrace to the temple at Delphi and its inscription, "Know Thyself," within the shrine was an oracle - a young woman from the village - who sat amidst vapors in a cave-like area. In response to questions posed to her about the future, she spoke in tongues, probably under the influence of ethylene, a volcanic gas with hallucinogenic effects (Spiller, Hale, \& De Boer, 2002). Temple priests then interpreted her forecasts. This close association of the command "Know Thyself," and oracular visions gives rise to Question 11: What is my future? This question remains relevant to psychology today, 
each time we predict from personality to life outcomes (Shea, Lubinski, \& Benbow, 2001).

Although the command "Know Thyself" on the Delphic Temple's column was a reasonable injunction at the time, the work of modern psychology has given rise to a discordant response: That self-knowledge is actually quite difficult, and there are many obstacles lying in its way (Funder, 1998, p. 150; Wilson \& Dunn, 2004). This concern is characterized in Question 12: Why is it so hard to know ourselves? Questions About a Science of Psychology

\section{The Beginnings of Modern Psychology}

As the sciences emerged as formal disciplines in the $19^{\text {th }}$ century many believed it was time to begin a science of psychology that would address some of the forgoing questions. A debate arose over Question 13: Is it possible to have a science of psychology? Acknowledging that people would resist a science of "thoughts, feelings, and actions," John Stuart Mill (1806-1873) nonetheless contended that such topics represented natural phenomena amenable to scientific study (Mill, 1900/1941, Book VI, Ch. III, Sec 1, 2).

Not everyone agreed. Auguste Comte (1798-1857), who had created a system for organizing all the sciences, skipped over psychology. Responding to what then seemed to be irresolvable debates as to how the mind operated, Compte regarded the nascent science as "an idle fancy, and a dream, when it is not an absurdity" (Levy-Bruhl, 1903, p. 191). Fortunately, others prevailed and the discipline of psychology was established. Locating the System of Study

Despite his skepticism, Comte's organizational system of the sciences left room for the study of the human mind between biology and sociology along a molecular-molar continuum. To fill in that gap meant locating psychology amid the systems to which it connected. Monte writes that "the most profound question of personality theory... has been, 'Where is the person?', (Monte \& Sollod, 2003, p. 5). He goes on to outline its possible places:

"hidden within...private thoughts, ...encoded by various parts of

the central nervous system, emerging from... [a] person's

relationships with others...".

It meant understanding Question 14: Where is personality?

The Tension Between Science and Humanity

The scientific study of personality introduces a tension between studying the person as a whole sentient being, and the more impersonal scientific methods of analysis commonly in use. For example, surveying the limited means by which personality was assessed in experimental studies, Carlson (1971) asked, "Where is the person in personality psychology?" - which is to say, does our science lose sight of the person?

Carlson's question seems to emerge from key concerns raised at the outset of the discipline - such as Allport's (1968, p. 377) inquiry: "How shall a psychological life history be written?". Allport sought a "full-bodied account" of personality. McAdams (1996) waxed epistemological, when he asked about the feeling of knowing another, in Question 15: What do we know when we know a person? 


\section{Questions of Personality Function and Change}

\section{The Operation of Personality and its Areas}

The question of how personality works is one often attributed to psychology by philosophers (Marinoff, 2000; Murphy \& Kovach, 1972, p. 13, 214). Questions of what causes the various characters have been raised since Antiquity (Robinson, 1976, p. 48). The psychiatric diagnosis of "Hysteria" for example, dates from Ancient Egypt when it was attributed to a wandering womb (Veith, 1970). Certainly, this isn't the real cause, but it represented a search for causes. Such exploration is reflected in Question 16: How does personality work?

In his book "On the Soul," De Anima, Aristotle argues the soul must be divided to be studied (Aristotle, 1976, Book I, IV, p. 51). For example, to distinguish human beings from animals requires understanding the parts of mind they share in common and those they do not. Aristotle divided the mind into nutritive, perceptive, locomotive systems, and a "universalizing" faculty by which abstract reasoning is carried out, among others (Murphy \& Kovach, 1972, p. 13; Robinson, 1976, p. 48). Aristotle rejects the philosophies of the soul to that time by concluding that they make the mistake of observing only one function of mind. He says functions must be divided, leading almost directly to its more modern variant, Question 17: How should personality be divided? Improving Personality: Issues of Personality Consistency and Change

Much of the study of personality stems from an ameliorative impulse, as well as a judgmental one. Judgment tells us what personality is; amelioration tells us how personality can become better. Hippocrates employed diet, laughter, and baths to ameliorate mental and physical suffering. The early Greek philosopher, Antiphon, had a doorplate advertising his capacities to cure grief and melancholy through conversation (Viney \& King, 2003, p. 50). Educators since antiquity have sought to teach character and character virtues.

By the 1920s, many educators hoped to put character education on a scientific footing. The ambitious research program, Character Education Inquiry, studied over 10,500 US students' virtues, with a focus on their will power and persistence (Cunningham, 2005). The researchers concluded that the school childrens' behaviors were surprisingly inconsistent: "There is no evidence of any trait of goodness or character if what is meant by goodness or character is just what may be observed or measured by conduct" (Hartshorne, May, \& Shuttleworth, 1930, p. 173). The lessons from such studies were sometimes interpreted to mean that character - or personality - might be largely illusory (Cantor \& Mischel, 1977; Cunningham, 2005; Shweder, 1975). Such findings prompted Question 18: Does personality exist?

By the 1980s, many researchers revisited the Character Education Inquiry program, more fully balancing its findings in light of new research. Scientists concluded that personality did exist and was often stable - though not, perhaps, in the simple terms conceived of at the beginning of the $20^{\text {th }}$ century (Funder, 2001; Kenrick \& Dantchik, 1983). A person's situation did matter: people "behave post office" in the post office, and "behave school" in school (Barker-Benfiled, 1992). For Mischel (1968, p. 301), "man's extraordinary adaptiveness," made identifying stability a challenging thing to do. This debate led to Question 19: How is personality expressed in the situation? 
Not to be put off by such uncertainties, psychologists continued to search for means of improving personality. Murray asked of the individual (Murray, 1938, p. 38) “...by what means can he be intentionally transformed?" Transformation requires understanding the conditions that lead a person to stay the same or change. Understanding that issue provides a basis for helping people to change as they desire (Pervin, 2002). It is worthwhile concluding this list of 20 with a reflection of such key concerns of the individual; that is, with question 20: Why do people stay the same or change?

\section{In Summary}

Twenty big questions of personality psychology were here collected. The list is just one of many possible lists of the big questions of personality psychology. The list can be characterized as largely Western in its orientation, and as emphasizing earlierasked questions relative to newer, more contemporary ones (although an attempt is made to chart the continuity between them). Other lists with different emphases would be welcome and complementary to the present effort. That said, it is likely that other such lists would contain considerable overlap. Any carefully selected and relatively complete list provides a good starting place list to illuminate matters of importance to the field.

\section{A MODEL OF KEY QUESTIONS}

\section{What Remain As Important Questions?}

The 20 big questions listed here provide a key summary of one aspect of the intellectual history of the field: a list of questions from antiquity to the present. Twenty questions, although of use in summarizing much thought, may themselves form a group that is large and unwieldy relative to a focus on the most important and unifying questions of personality psychology. The functional, unifying aspects of asking questions can be highlighted by selecting a subset of key questions.

Several approaches were employed to screen out the least important questions and to identify the most important or key questions. Generally speaking, it seems most useful to retain questions that are still relevant in that they have not yet been answered, and yet that are considered productive (versus intractable), of subjective interest, and scientifically important.

\section{Questions Unanswered and Answered}

Some questions on the list already have been answered and could plainly be set aside as they have less pertinence to present-day endeavors. For example, consider the question, "Is it possible to have a science of psychology?". The question reflected a preempirical consideration of what the discipline might be like. Although the answer to this question (any question, really) can be argued in some trivial sense, the thousands of psychological laboratories operating worldwide today indicate that a pragmatic answer has been established: "Yes." A similarly already-answered question of antiquity (though not on this list) is, "Can anything be known?".

Another group of questions, though not so cleanly answered, have been substantially addressed and their answers appear more context-specific than originally believed. For example, the question, "To what degree is personality learned or innate?" has been addressed to a considerable degree, and we now understand and separate out 
genetic, environmental, and interactive influences, for example, for specific traits (e.g., Grigorenko, 2000).

Questions Outside the Discipline

Still other questions were separated out from psychology at the field's scientific inception. For example, early psychologists carefully drew boundaries for the field, emphasizing that it would deal with natural as opposed to supernatural phenomena (e.g., James, 1892/1920; Wundt, 1897). So, for example, the question "Can human beings know God?" was defined as outside the terrain of scientific psychological work from the inception of the discipline onward.

Questions Recast More Productively

Another group of questions, including "Are mind and body the same?" and "Is there free will?" appear to have been less productive to ask than originally foreseen. This group is undergoing some recasting so as to make them more productive (and, perhaps, less big). For example, "Is there free will?" has been recast more on the order of "What is voluntary action and when does it take place?" (Flanagan, 2002; Wegner, 2004).

The Subjective Interest Level of Questions

Questions also can be judged according to their subjective interest level. Certain questions, such as "Who am I?" and "How does a person change?" appear across textbooks of the field. These and related questions appear of continuous interest to those attracted to the field. To discover which, if any, of the 20 questions were particularly interesting, one important stakeholder group in the field, university students, were polled. Brief Demonstration Study

The study included 126 undergraduates ( 82 women; 44 men). Participants read the 20 questions identified here and 10 more selected from personality psychology textbooks. (There were two exceptions: Questions 2 and 18 were added subsequent to the study; and Question 19 was rephrased for clarity after the study). The questions were blocked into groups of 10 and then counterbalanced as to order. Participants rated each question on a 5-point Likert scale from 1 (not at all) to 5 (very interesting). The five most interesting questions (followed by their mean ratings) were: "What is my future?" (4.4), "Who am I?" (4.3), "Why do people stay the same or change?" (4.1), "How shall I live my life?" 4.0), and "Is there free will?" (4.0). The least interesting questions, by contrast, involved already-answered issues (e.g., "Is it possible to have a science of psychology?" (3.2) or methodological issues such as "How should personality be divided?" (3.1). These findings indicate that although all the questions were considered interesting, questions of identity and change were particularly intriguing. Other central questions that are oriented toward scientific procedures and approaches are less intrinsically interesting, although they remain instrumental themselves in the pursuit of scientific answers to the most interesting questions.

\section{The Most Central Questions}

Focusing on the most productive, interesting, and scientifically-relevant questions yields a reduced set that can be conveniently categorized into four groups. These four central groups include (a) identity questions such as "What is human nature?", "Who am I?", and "What is my future?", (b) questions related to social interaction such as, "Why are people different from one another?", (c) questions of adaptation such as "Why do 


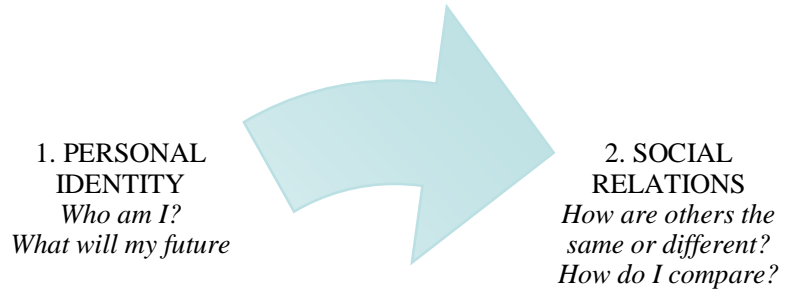

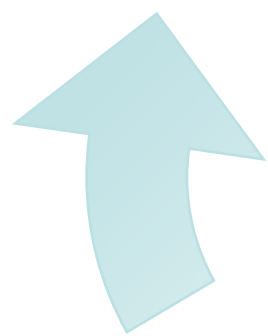

4. SCIENTIFIC RESEARCH

How can I find the

best answers to my questions?

How is personality best studied? RELATIONS same or different? How do I compare?

3. ADAPTATION AND CHANGE How can I change? If I can, how can I improve my own and others' future?

Figure 1. A Big Questions Model. One way to interrelate key questions of personality psychology is to envision them as forming a sequence from questions of identity to questions about social interactions, personal adaptation, and finally, to the best ways, scientifically speaking, of answering such questions.

people stay the same or change?", and (d) questions of scientific research such as, "How does personality work?" and "How should personality be divided?".

A Model of Big Questions About Personality

These four groups of questions: of (a) personal identity, (b) social relations, (c) adaptation and change, and (d) scientific research, can be organized together to make them easier to recall and discuss as a group. One way to do so is to begin with an individual's identity questions, illustrate how those lead to social comparisons, which then lead to questions of change, and conclude, finally, by identifying the best answers to such questions through scientific methods. Such an approach conveniently joins the most naturally interesting big questions (e.g., "Who am I?" "What will my future be?") with the scientific questions necessary to answer them. 
The Big Question model begins with an individual who wonders, "Who am I?" and "What will my future be?" (see Figure 1, top left). Most personality psychologists agree that the personality system must create a self-model (an identity), and obtain feedback regarding it (Erikson, 1963; Fredrickson \& Losada, 2005). Such a model and the feedback on it are necessary for social performance in general, and to predicting and controlling the environment (Carver \& Scheier, 2002; Karoly, 1999; Kelly, 1955). Selfknowledge also is important so that the individual can choose to be in environments compatible with his or her personality where possible (Gottfredson \& Holland, 1990; Setterlund \& Niedenthal, 1993). The absence of any self-understanding may be regarded as a worrisome flaw that impairs such decisions (Setterlund \& Niedenthal, 1993).

"Who am I?" however, cannot be answered without learning from and comparing oneself to others. Children early-on develop theories of others' models of mind (Symons, 2004). "Who am I"?, in other words, leads to "Who are you?". This line of thought leads to "Why - and how - are people different?".

Following this line of thought, the model continues with questions of Social Relations, generally - of wondering about who others are and how to interact with them (Figure 1, top right). (The questions have been slightly rephrased to better follow from one another, while retaining their original foci). Working from an evolutionary perspective, David Buss has noted how understanding others is crucial to survival: Selecting the right hunting partner is a matter of life and death; selecting the right mate is a matter of survival of one's descendents (Buss, 2001). We also continue to compare ourselves to others. Social-comparison processes help the individual further understand who he or she is, and how one's particular identity compares to others (Mussweiler, Rüter, \& Epstude, 2004; Wood, 1989). This social comparison aspect of the question, "How are others the same or different?" can be stated as "How do I compare?".

The model continues with questions of adaptation and change (Figure 1, bottom right). In the course of social comparison and more generally planning interactions, a person may decide that someone else's personality is particularly admirable, or attracts more rewards. This gives rise to the third group of questions, involving adaptation and change: "Why do people stay the same or change?" and "How might I change?" These concern how a person might change (for example, to become more similar to an admired friend). Closely associated would be the idea, "If I change, how might my future change?".

Two centuries ago, these questions might have seemed to form a complete, tightly knit group. It is a hallmark of contemporary ideas, however, that we attempt to improve our questions and answers through scientific research. Scientific investigations, in this context, are motivated by an overarching concern: "How can I get the best answers to questions about personality?" By addressing big questions with scientific procedures and methods, better answers to each one are possible. Questions about the methods of scientific inquiry exist in a service relationship to the most central big questions. Although the scientific questions are superficially less interesting, they nonetheless are crucial to the discipline and to obtaining good answers (Figure 1, bottom left).

The answers to questions about the self, others, and personal change produce research which then leads to a new, refined set of questions and the cycle of inquiry begins again - as represented by the continuous form of the diagram. Collectively, the 
Big Question model summarizes a number of the particularly key questions of the discipline.

\section{DISCUSSION}

Questions, Answered and Unanswered

Posing a question denotes a point of connection - a transition point - an abutment, between the known and unknown. Asking a question is like standing on a shore between the land of knowledge, and a sea of uncertainty, secrecy, and mystery. A question marks the transition from the known to the unknown, just as certainly as the shore marks the transition from land to sea, and both elicit our natural wonder.

The standpoint from which a question is asked, like the physical shore, shifts as the knowns and unknowns around it change their shapes. In this article, 20 big question of personality psychology, and psychology more generally, were identified, and discussed. The 20 personality-relevant questions collected in the second section of this article, combine those that, today, primarily are of importance to intellectual history as well as those that still hold personal and scientific meaning. Next, a model was developed that involved the most important among those questions for the discipline: questions of identity, social relations, adaptation, and scientific research. Finally, it is fair to ask how knowledge of these questions can help the discipline and those who work within it?

Applications of Questions

The field of personality psychology is increasingly technical; textbooks increasingly downplay the early- $20^{\text {th }}$-century theories that, earlier, had provided some connections between the discipline and more general concerns (e.g., Derlega, Winstead, \& Jones, 1991; Larsen \& Buss, 2005; Mayer, 2007; McAdams, 2006; Pervin, 2003). Walking students through the big questions themselves, however, can provide an overview of the significance of what personality psychology now teaches. The progression from "Who am I?" to "How are people different?" to "How might I change?" to "How can I obtain good answers?" follows one sequence of thinking that, judging from the big-question qualities involved, should resonate with thoughtful people. The inquiry model presented here can help communicate the discipline. The model, which represents one way the questions interrelate, provides an account of how they fit together and the functions they accomplish. This better describes a focus of the discipline and is likely to engage others.

Many, if not all, of the research topics studied in personality psychology address one or more of those questions. For example, the "Who am I?" question draws on research concerning traits, self and identity, and the relation among motives, emotions, cognition, and the self. The question "How are others the same or different?" involves traits again, but with an emphasis on individual differences, and also the psychology of person perception, stereotyping, and causal influences on the mental system. The question "How can I change?" brings in research on self-control, clinical therapeutic techniques, and the form of personality stability and change (Janoff-Bulman \& Schwartzberg, 1991; Prochaska \& Norcross, 2003). Finally, questions of science concern all the major theoretical, methodological and procedural research of the field. 


\section{CONCLUSIONS: KEY QUESTIONS AS INTEGRATIVE GOALS}

Earlier in the century, personality psychologists were often divided by the theoretical perspective they employed: psychodynamic, or trait, or social-cognitive. Different theories employed different languages and emphasized different issues (Hall \& Lindzey, 1957; Mayer, 2005b; McAdams, 2006; Westen, 1991). Today, remnants of the different-theories tradition, along with the isolation provided by specialization in one research area or another, continue to provide barriers to working together.

Big questions have arguably served as a cohesive and unifying force for the discipline in the face of such divisions. The question, "Why do people stay the same or change?" was as important to the psychoanalyst as to the behaviorist in the 1950s (or any other time). In the 2000s, the question of "Why are people different?" matters as much to the trait psychologist as to the social-cognitive psychologist.

As more evidence for this proposition, most or all research areas in the field can be associated with one or another of the questions. "Who am I?" is examined by research on personality parts such as emotions and cognition, and structures. Both "Who am I?" and "How are people different?" are addressed by studies of traits and individual differences. "How do people change?" is examined by researchers studying personality expression and dynamics. Finally, procedures and methods help us answer "How can I get the best answers (about personality) I can?".

The work of personality psychologists is unified by interest in questions such as "Who am I?" and "How are people different?" across theoretical perspectives and research interests. The Big Questions model developed here personalizes some of the most important questions in a sequence of inquiry and discovery, from "Who am I", to "How is personality studied scientifically?", and back again to self-understanding. Such big questions, then, represent a force holding the field together. Understanding and communicating these big questions can help encourage those studying the field, motivate those working in the field, and explain the interest and significance of the field to others.

\section{REFERENCES}

Alexander, F. (1942). Our age of unreason. Philadelphia: Lippencott.

Allport, G. W. (1937). Personality: A psychological interpretation. New York: Holt.

Allport, G. W. (1964). The fruits of eclecticism: Bitter or sweet? . Acta Psychologica, 23, $27-44$.

Anastasi, A., \& Foley, J. P. (1949). Differential Psychology. New York: Macmillan.

Aristotle. (1976). Ethics (J. A. K. Thompson, Trans.). London: Penguin Books.

Bacon, F. (1605/1878). Of the proficience and advancement of learning divine and human. In The works of Francis Bacon (Vol. 1, pp. 236). Cambridge: Hurd and Houghton.

Bain, A. (1868/1973). Mental science. New York: Arno Press.

Barker-Benfiled, G. J. (1992). The culture of sensibility: Sex and society in Eighteenthcentury Britain. Chicago, IL: University of Chicago Press. 
Bart, C. K., \& Baetz, M. C. (1998). The relationship between mission statements and firm performance: An exploratory study. Journal of Management Studies, 35, 823-853.

Bart, C. K., \& Tabone, J. C. (2000). Mission statements in Canadian not-for-profit hospitals: Does process matter? Health Care Management Review, 25, 45-63.

Bartkus, B., Glassman, M., \& McAfee, R. B. (2000). Mission statements: Are they smoke and mirrors? Business Horizons, 43, 23-28.

Bonwell, C. G., \& Eisen, J. A. (1991). Active learning: Creating excitement in the classroom (pp. 7-31). Washington, DC: ERIC Clearinghouse on Higher Education.

Buss, D. M. (2001). Human nature and culture: An evolutionary psychological perspective. Journal of Personality, 69, 955-978.

Cantor, N., \& Mischel, W. (1977). Traits as prototypes: Effects on recognition memory. Journal of Personality and Social Psychology, 35(1), 38-48.

Carlson, R. (1971). Where is the person in personality research? Psychological Bulletin, 75, 203-219.

Carver, C. S., \& Scheier, M. F., Vol (4), . pp. . (2002). Control processes and selforganization as complementary principles underlying behavior. Personality \& Social Psychology Review, 6, 304-315.

Chomsky, N. (1965). Aspects of the theory of syntax. Oxford, England: M.I.T. Press.

Cunningham, C. A. (2005). A certain and reasoned art: The rise and fall of character education in America. In D. K. Lapsley \& F. C. Power (Eds.), Character psychology and character education. Notre Dame, Indiana: University of Notre Dame.

Derlega, V. J., Winstead, B. A., \& Jones, W. H. (Eds.). (1991). Personality: Contemporary theory and research. Chicago: Nelson-Hall.

Descartes. (1641/1968). Discourse on Method and the Meditations (F. E. Sutcliffe, Trans.). New York: Penguin.

Diodurus. (1935/1960). Diodurus of Sicily. Harvard University Press: Cambridge, Massachusetts.

Erikson, E. H. (1963). Childhood and society (2nd ed.). New York: W. W. Norton and Company.

Flanagan, O. J. (2002). The problem of the soul: Two visions of mind and how to reconcile them. New York: Basic Books.

Fredrickson, B. L., \& Losada, M. F. (2005). Positive Affect and the Complex Dynamics of Human Flourishing. American Psychologist, 60, 678-686.

Funder, D. C. (1998). Why does personality psychology exist? Psychological Inquiry, 9, 150-152.

Funder, D. C. (2001). The personality puzzle. New York: W. W. Norton \& Company.

Gottfredson, G. D., \& Holland, J. L. (1990). A longitudinal test of the influence of congruence: Job satisfaction, competency utilization, and counterproductive behavior. Journal of Counseling Psychology, 37, 389-398.

Green, C. D., \& Groff, P. R. (2003). Early psychological thought. Westport, CT: Praeger.

Grigorenko, E. L. (2000). Heritability and intelligence. In R. J. Sternberg (Ed.), Handbook of intelligence (pp. 53-91). Cambridge, UK: Cambridge University Press. 
Griswold, C. L. (1986). Self-knowledge in Plato's Phaedrus. New Haven: Yale University Press.

Hall, C. S., \& Lindzey, G. L. (1957). Theories of Personality. New York: Wiley.

Hall, C. S., \& Lindzey, G. L. (1978). Theories of personality (3rd ed.). New York: John Wiley \& Sons.

Hamilton, R. J. (1985). A framework for the evaluation of the effectiveness of adjunct questions and objectives. Review of Educational Research, 55, 47-85.

Hartshorne, H., May, M., \& Shuttleworth. (1930). Studies in the nature of character, Volume 3: Studies in the organization of character. New York: Macmillan.

Henle, M. (1976). Why study the history of psychology? Annals of the New York Academy of Sciences, 270, 14-20.

Husserl, E. (1913/1931). Ideas: General introduction to pure phenomenology (W. R. R. Gibson, Trans.). New York: The MacMillan Company.

James, W. (1892/1920). Psychology: Briefer course. New York: Henry Holt.

Janoff-Bulman, R., \& Schwartzberg, S. S. (1991). Toward a general model of personal change. In C. R. Snyder \& D. R. Forsyth (Eds.), Handbook of social and clinical psychology. New York: Pergamon Press.

Jaynes, J. (1973). Introduction: The study of the history of psychology. In M. Henle, J. Jaynes \& J. J. Sullivan (Eds.), Hsitorical conceptions of psychology. New York: Springer.

Jaynes, J. (1976). The origin of consciousness in the breakdown of the bicameral mind. Boston: Houghton Mifflin.

Jerusalem Bible. (H. Fisch, Trans.)(1992). H. Fisch, Trans.). Jerusalem: Koren Publishers.

Jung, C. G. (1923). Psychological Types, or, the Psychology of Indivduation (H. G. Baynses, Trans.). New York: Harcourt, Brace \& Company.

Karoly, P. (1999). A goal systems-self-regulatory perspective on personality, psychopathology, and change. Review of General Psychology, 3, 264-291.

Kelly, G. A. (1955). The psychology of personal constructs. Volume One: A theory of personality. New York: W. W. Norton.

Kenrick, D. T., \& Dantchik, A. (1983). Interactionism, idiographics, and the social psychological invasion of personality. Journal of Personality, 51, 286-307.

Kunzendorf, R. G. (1982). Journal of Mental Imagery. 6, 183-201.

La Coste-Messelière, P. (1950). The treasures of Delphi [Photographs by Georges de Miré]. Paris: Éditions du Chêne.

Larsen, R. J., \& Buss, D. M. (2005). Personality psychology: Domains of knowledge about human nature (2nd ed.). Boston: McGraw-Hill.

Levy-Bruhl. (1903). The philosophy of August Comte. London:: Swan Sonnenschein.

Marinoff, L. (2000). Plato, not Prozac! Applying philosophy to everyday problems. New York: Harper Perennial.

Mayer, J. D. (2005a). A tale of two visions: Can a new view of personality help integrate psychology? American Psychologist, 60, 000-000.

Mayer, J. D. (2005b). A tale of two visions: Can a new view of personality help integrate psychology? American Psychologist, 60, 294-307.

Mayer, J. D. (2007). Personality: A Systems approach. Boston: Pearson Allyn \& Bacon. 
McAdams, D. P. (1996). Personality, Modernity, and the storied self: A contemporary framework for studying persons. Psychological Inquiry, 7(4), 295-321.

McAdams, D. P. (2000). The Person: An integrated introduction to personality psychology. Fort Worth, TX: Harcourt College Publishers.

McAdams, D. P. (2006). The person: A new introduction to personality psychology (4th ed.). Hoboken, NJ: John Wiley \& Sons.

Mill, J. S. (1900/1941). A system of logic : ratiocinative and inductive, being a connected view of the principles of evidence and the methods of scientific investigation. London, New York: Longmans, Green.

Mischel, W. (1968). Personality and assessment. New York: John Wiley \& Sons.

Mischel, W., \& Shoda, Y. (1995). A cognitive-affective system theory of personality: Reconceptualizing situations, dispositions, dynamics, and invariance in personality structure. Psychological Review, 102, 246-268.

Mischel, W., Shoda, Y., \& Smith, R. E. (2004). Introduction to Personality. Hoboken, NJ: Wiley.

Monte, C. F., \& Sollod, R. N. (2003). Beneath the mask: An introduction to theories of personality (7th ed.). New York: Wiley.

Murphy, G., \& Kovach, J. K. (1972). Historical introduction to modern psychology. New York: Harcourt Brace Jovanovich.

Murray, H. A. (1938). Explorations in personality. New York: Oxford University Press.

Mussweiler, T., Rüter, K., \& Epstude, K. (2004). The Ups and Downs of Social Comparison: Mechanisms of Assimilation and Contrast. Journal of Personality \& Social Psychology, 87, 832-844.

Nagel, T. I. E. (1981). What is it like to be a bat? In D. R. Hofstadter \& D. C. Dennett (Eds.), The mind's I: Fantasies and reflections on self and soul. (pp. 000-000. [Original work published 1974 in Philosophical Review].). New York: Basic Books.

Pervin, L. A. (2002). Current controversies and issues in personality (3rd ed.). New York: John Wiley \& Sons.

Pervin, L. A. (2003). The science of personality (2nd ed.). New York: Oxford University Press.

Pervin, L. A., Cervone, D., \& John, O. P. (2005). Personality: Theory and Research (9th ed.). New York: John Wiley \& Sons.

Prochaska, J. O., \& Norcross, J. C. (2003). Systems of psychotherapy: A transtheoretical approach. Pacific Grove, CA: Brooks/Cole.

Roback, A. A. (1927). The psychology of character. New York: Harcourt, Brace, \& Company.

Roback, A. A. (1928). The psychology of character with a survey of temperament. New York: Harcourt Brace \& Company.

Robinson, D. N. (1976). An intellectual history of psychology. New York: MacMillan Publishing Company.

Ryan, R. M., \& Deci, E. L. (2000). Self-determination theory and the facilitation of intrinsic motivation, social development, and well-being. American Psychologist, 55, 68-78.

Sears, R. R. (1950). Personality. Annual Review of Psychology, 1, 105-118. 
Setterlund, M. B., \& Niedenthal, P. M. (1993). "Who am I? Why am I here?" Selfesteem, self-clarity, and prototype matching. Journal of Personality \& Social Psychology, 65, 769-780.

Shea, D. L., Lubinski, D., \& Benbow, C. P. (2001). Importance of assessing spatial ability in intellectually talented young adolescents: A 20-year longitudinal study. Journal of Educational Psychology, 93, 604-614.

Shweder, R. A. (1975). How relevant is an individual differences theory of personality. Journal of Personality, 43, 455-484.

Smith, R. (1998). The big picture: Writing psychology into the history of the human sciences. Journal of the Behavioral Sciences, 34, 1-13.

Spiller, H. A., Hale, J. R., \& De Boer, J. Z. (2002). The Delphic Oracle: A multidisciplinary defense of the gaseous vent theory. Journal of Toxicology -Clinical Toxicology, 40, 189-196.

Stace, W. T. (1924/1955). The philosophy of Hegel: A systematic exposition. New York: Dover.

Symons, D. K. (2004). Mental state discourse, theory of mind, and the internalization of self-other understanding. Developmental Review, 24, 159-188.

Theophrastus. (372-287 B.C./1929). Demarcated characters. In Edmunds (Ed.), The characters of Theophrastus.

Veith, I. (1970). Hysteria: The history of a disease. Chicago: University of Chicago Press.

Viney, W., \& King, D. B. (2003). A history of psychology: Ideas and context (3rd ed.). Boston: Allyn \& Bacon.

Watson, R. I. (1967). Psychology: A prescriptive science. American Psychologist, 22, 435-443.

Wegner, D. M. (2004). Précis of The illusion of conscious will. Behavioral \& Brain Sciences, 27, 649-659.

Westen, D. (1991). Social cognition and object relations. Psychological Bulletin, 109, 429-455.

Wilson, T. D., \& Dunn, E. W. (2004). Self-Knowledge: Its limits, value, and potential for improvement. Annual Review of Psychology, 55, 493-518.

Wood, J. V. (1989). Theory and research concerning social comparisons of personal attributes. Psychological Bulletin, 106, 231-248.

Woodhouse, M. B. (1984). A preface to philosophy (3rd ed.). Belmont, CA: Wadsworth Publishing.

Wundt, W. (1897). Outlines of psychology (C. H. Judd, Trans.). Leipzig: Wilhelm Englemann. 